Relations industrielles

Industrial Relations

\title{
Working Disasters : The Politics of Recognition and Response Edited by Eric Tucker. Amityville, N.Y. : Baywood Pub., 2006, 325 p., ISBN 0-895033-19-4 (cloth).
}

\section{Marc Baril}

Volume 64, numéro 1, hiver 2009

URI : https://id.erudit.org/iderudit/029548ar

DOI : https://doi.org/10.7202/029548ar

Aller au sommaire du numéro

Éditeur(s)

Département des relations industrielles de l'Université Laval

ISSN

0034-379X (imprimé)

1703-8138 (numérique)

Découvrir la revue

Citer ce compte rendu

Baril, M. (2009). Compte rendu de [Working Disasters : The Politics of Recognition and Response Edited by Eric Tucker. Amityville, N.Y. : Baywood Pub., 2006, 325 p., ISBN 0-895033-19-4 (cloth).] Relations industrielles / Industrial Relations, 64(1), 174-176. https://doi.org/10.7202/029548ar

Tous droits réservés (C Département des relations industrielles de l'Université Laval, 2009
Ce document est protégé par la loi sur le droit d'auteur. L'utilisation des services d’Érudit (y compris la reproduction) est assujettie à sa politique d'utilisation que vous pouvez consulter en ligne.

https://apropos.erudit.org/fr/usagers/politique-dutilisation/ 
et la sous-utilisation des compétences). En ce qui a trait à la deuxième section, l'auteure établit les recommandations qui s'imposent en regard au droit à la santé appliqué au domaine du travail. En bref, il s'agirait de réaffirmer une zone d'interdits sociaux face aux facteurs de risques les plus virulents et aux atteintes les plus graves. L'auteure propose aussi des améliorations dans les mécanismes de recours pour les travailleurs, de même que des moyens pour la prévention des facteurs de risques et des situations d'atteintes.

L'incidence des transformations du travail sur les travailleurs constitue une question essentielle qui, du moins jusqu'à présent, a fait l'objet de bien peu de recherches. L'ouvrage recensé constitue un excellent tour d'horizon de plusieurs facteurs de risques actuellement présents dans les milieux de travail, ainsi que de leurs conséquences psychologiques. Cependant, il aurait été intéressant, puisque cet ouvrage expose et analyse les conditions de travail émergeant des transitions du travail, de tracer des parallèles avec les conditions de travail antérieures aux changements mentionnés. En fait, l'auteure souligne bien le fait que la charge mentale du travail s'accroît actuellement, alors qu'auparavant c'était la charge physique. Toutefois, quelques facteurs de risques abordés pourraient trouver leur origine dans les modes de production plus anciens (ex., le contrôle est également très présent dans le mode de production fordiste, mais $d^{\prime}$ 'une manière différente). Par ailleurs, la classification des facteurs de risques diffère de celle rencontrée habituellement dans le champ des relations industrielles. Par exemple, la définition de l'« organisation du travail » adoptée par l'auteure inclut différents modes de production (ex., le « juste-à-temps ») et de gestion des ressources humaines (ex., la gestion au mérite), mais l'auteure n'y inclut pas les conditions de travail (ex., la robotisation et la marge de manœuvre). II reste tout de même que cet ouvrage représente une excellente synthèse des risques à la santé psychologique dans le contexte de travail actuel, qui a également le mérite de soulever le besoin d'adapter les législations ainsi que les mécanismes de recours aux transformations que connaît présentement le monde du travail.

\section{Marie-Michelle Gouin}

Université Laval

\section{Working Disasters : The Politics of Recognition and Response}

Edited by Eric Tucker. Amityville, N.Y. : Baywood Pub., 2006, 325 p., ISBN 0-895033-19-4 (cloth).

Le but ultime de cet ouvrage est de faire prendre conscience au lecteur des interrelations entre des événements ou incidents survenus principalement en milieu de travail qui, dans certains cas, s'échelonnent sur plusieurs décennies et la ou les réponses du législateur sous la pression de l'opinion publique, de même que l'évolution de cette réponse dans le temps.

L'origine de même que la formation des auteurs des dix chapitres qui composent cet ouvrage expliquent la diversité des exemples présentés. Le fait de mettre l'accent sur le milieu de travail ne permet pas d'aborder I'un des plus beaux cas existant actuellement, à savoir celui de la Directive européenne de Seveso, tout comme l'absence d'un auteur issu du Québec ne permet pas de traiter du cheminement ayant conduit à la mise en œuvre en 1980 de la Loi sur la santé et la sécurité du travail, initiée notamment par la problématique des travailleurs de l'amiante.

Le premier chapitre se veut une introduction dans laquelle le directeur de la publication rappelle, suite à une revue de littérature particulièrement intéressante, les divers aspects d'un désastre et de ses conséquences tant au niveau du public qu'à celui du législateur.

Dans le deuxième chapitre, des auteurs australiens analysent l'impact, en termes de décès, d'accidents et de maladies professionnelles, du transport routier de longue distance en Australie, mais surtout l'absence de réponse des autorités en place. Ces dernières semblent considérer cette problématique comme externe au mode de production et l'excluent conséquemment des mécanismes habituels d'indemnisation des accidents et maladies professionnelles. Cette problématique australienne est un reflet miroir de ce que l'on retrouve de plus en plus en Amérique du Nord. Au cours des dernières années, aux États-Unis seulement, le nombre de compagnies de transport recensées est passé de 30000 dans les années 1980 à plus d'un demi-million au début des années 2000, avec des conséquences semble-t-il similaires. 
Toujours sous la plume d'un auteur australien, le troisième chapitre décrit pour ce pays une réalité vécue dans tous les pays développés à la fin des années 1980 et au début des années 1990, celle de la reconnaissance des troubles musculosquelettiques comme maladie professionnelle, notamment les tendinites et autres liées à I'utilisation de plus en plus intense de l'informatique dans le travail de tous les jours.

Le chapitre 4, écrit par un auteur canadien, procède à une description de la problématique liée aux mines de Fluospar de St. Lawrence à Terre-Neuve et expose la manière dont elle a façonné, de 1933 à 1978 donc sur plus de quatre décennies, le volet compensation des accidents et maladies professionnelles dans cette province canadienne. Ce chapitre, qui aurait sa place dans un manuel d'histoire, fait bien ressortir l'évolution des connaissances médicales, notamment sur la silicose, du rôle des acteurs tant patronaux que syndicaux, des diverses commissions d'enquêtes qui se sont succédé et ce, parallèlement à l'évolution de la législation terre-neuvienne en matière de reconnaissance des maladies professionnelles et d'indemnisation des travailleurs.

Dans la même veine que le précédent, le chapitre 5 décrit avec moult détails la problématique de la silicose en Suède et comment cette dernière a influencé la législation suédoise tout au cours du vingtième siècle.

Le chapitre 6, particulièrement bien documenté, se démarque des chapitres précédents qui portaient principalement sur des maladies professionnelles, en traitant d'un effondrement d'édifice survenu le 10 janvier 1860 à Lawrence (Massachussetts) et dans lequel plusieurs centaines de femmes et de jeunes filles immigrantes irlandaises perdirent la vie. L'auteur explique en quoi les interrogations et rapports produits sur ce désastre ont changé la perception du public américain sur les travailleurs des manufactures, et en quoi également ce désastre a entraîné, d'une certaine manière, la mise en œuvre des premières mesures d'indemnisation des travailleurs décédés ou blessés au travail.

Plus près de nous, le chapitre suivant traite d'un autre désastre survenu le 6 juillet 1988 en Mer du Nord. Le désastre de la plateforme de production pétrolière Piper Alpha tire son origine d'un manquement du système de surveillance réglementaire décrit comme « the institutionalization of tolerance », doublé d'une vision corporative partagée par l'ensemble de l'industrie surnommée " the political economy of speed ». Cet ensemble de facteurs non nécessairement propres aux années 1970 et 1980 au Royaume-Uni permet d'expliquer en quelques mots la dynamique inhérente à cet événement. L'auteur analyse comment les milieux tant corporatifs que gouvernementaux ont réagi. II fait ressortir également en quoi les nouvelles approches mises en place sont d'une certaine façon discriminatoires pour les travailleurs.

Le chapitre 8 est potentiellement déroutant pour un lecteur habitué à un système légal basé sur le code de Napoléon. Par ailleurs, ce même lecteur aura, grâce notamment au dynamisme de l'auteur et à son écriture fluide, un aperçu du système législatif australien basé sur la common law. Ce chapitre plus juridique ouvre bien la porte aux deux derniers chapitres de ce volume qui traitent, d'une part, des mines houillères de la Nouvelle-Écosse de 1858 à 1992 et, d'autre part, des conséquences du désastre de la mine Westray survenu en 1992.

Le chapitre 9 fait un retour en arrière sur les multiples enquêtes ou commissions d'enquêtes de tous genres qui au cours des ans ont vu le jour suite à des incidents dans les mines de charbon de la province. L'auteur ayant regroupé celles-ci par périodes (18581879, 1880-1969, 1970-Westray), il peut ainsi présenter l'évolution des mentalités des principaux acteurs, ainsi que les modifications apportées aux diverses lois et réglementations s'appliquant à ce secteur.

Le dixième et dernier chapitre permet au directeur de l'ouvrage de présenter et d'expliquer un modèle des divers déterminants en cause lors d'un désastre industriel en utilisant le désastre de Westray comme base explicative. Si dans sa conclusion il traite des possibilités de modifier le Code criminel canadien pour y inclure certains éléments de responsabilité des entreprises et de leurs administrateurs, il ne traite malheureusement pas de l'aspect diligence raisonnable qui représente actuellement un incontournable pour tous les acteurs en milieu industriel au Canada, compte tenu des 
modifications récentes qui ont effectivement été apportées au Code criminel canadien.

De façon générale, on ne peut que recommander la lecture de ce livre notamment aux personnes impliquées en santé et sécurité du travail. II permet au lecteur d'être à même de visualiser les conséquences à long terme sur la santé et la sécurité de certaines décisions prises sans analyse de risque préalables. Par ailleurs il ouvre une fenêtre sur des événements survenus hors du Québec dont on parle très peu sinon jamais dans les cours de formation en santé et sécurité du travail, même si, dans certains cas, certains d'entre eux ont un impact de plus en plus important sur nos façons de faire, comme I'illustre notamment le cas Westray.

\section{Marc Baril}

Institut de recherche Robert-Sauvé en santé et sécurité du travail

\section{Growing Older, Working Longer: The New Face of Retirement}

By Monica Townson. Ottawa: Canadian Centre for Policy Alternatives, 2006, 254 pp., ISBN 0-886274-73-7 (pbk.).

Perhaps it is because I am a recently retired person of a "certain" age that I found this book to be such a relevant, informative and fascinating read. But I believe that the author, Monica Townson, has put together a well researched publication of such fundamental significance that it should be high on the reading list of anyone seeking to acquire, or enhance, an understanding of its subject matter.

It is written in a mainly commentarial style rather than putting forward a thesis requiring justification. As its title makes clear, the book concerns the increasing longevity of the population and the implications for retirement that flow from that. Whilst the author's primary focus is on Canada, she has cleverly woven a global context into the tapestry of the book. Relevant ongoing experience drawn from various other well-developed, industrialized countries has been incorporated and analyzed, as have authoritative contributions from influential international bodies including the Organization for Economic Co-operation and Development (OECD), the International Monetary Fund (IMF), the World Health Organization (WHO), the United Nations (UN) and the European Union (EU).
The book comprises six chapters and its major themes are: the changing nature of retirement; trends in, and the adequacy of, the pension system; the reactions of governments and employers to the perceived challenges posed by the aging population and the baby boomer generation; the need to protect older workers; and the changing role and special needs of women.

In terms of the changing nature of Canadian retirement the author presents a useful historical perspective. At the beginning of the twentieth century, when employment was largely farm-based, retirement was virtually non-existent. Change began with the introduction of the Old Age Pension in 1927, which was later modified in 1951 with the introduction of the Old Age Security Act making the pension universal for the first time. In 1964 the federal government introduced the Canada Pension Plan (CPP) and the Guaranteed Income Supplement (GIS) in 1967. In addition, the provision of employer sponsored pensions improved the financial security of those employees who had them, as did the advent of Registered Retirement Savings Plans (RRSPS).

Partly in response to youth unemployment, early retirement provisions were added to the CPP in the mid-1980s to encourage people to retire early. The marketing slogan "Freedom $55^{\prime \prime}$ created by a major insurance company consolidated this approach to retirement in the minds of the public. The author draws on statistics to show that in 1976 the median retirement age for both men and women was 65 with a gentle downward trend thereafter to 1985 , falling more steeply from then until about 1997. Since that time it stabilized and increased slightly by 2002 . One small problem I had in this connection was the sudden introduction of "average" figures which I couldn't confirm by reference to the relevant table, as all discussion and statistics quoted till then were "medians."

The approach taken with regard to the discussion of challenges facing the pension system was to both review the evolvement in Canada and compare and contrast it with what was happening in other countries or the pronouncements of organizations such as the OECD, IMF, WHO, UN and EU. Townson 